\title{
Evaluation of the Nutritional and Sensory Quality of Nutri-Dense Products for Pre-Schoolers
}

\author{
Barbhai Mrunal D. ${ }^{1}$, Vijayalakshmi D. ${ }^{2}$, Subbarayappa C. T. ${ }^{3}$ \\ ${ }^{1}$ MSc Student, Dept. Food Science and Nutrition, University of Agricultural Sciences, GKVK, Bengaluru -65 \\ ${ }^{2}$ Professor and Head, Dept. Food Science and Nutrition, University of Agricultural Sciences, GKVK, Bengaluru -65 \\ ${ }^{\mathbf{3}}$ Professor, Dept. of Soil Science and Agricultural Chemistry, University of Agricultural Sciences, GKVK, Bengaluru -65
}

\begin{abstract}
Preschool children fall in the age group of 1-6 years. They eat four to six times a day making snacks one of the important meals contributing to daily nutrient intake. Thus, present study was conducted with objective to formulate nutrient dense products for pre-schoolers. Products formulated viz., nutri chips and veggi sticks were evaluated with 9-point hedonic scale. Results showed that fried nutri chips and veggi sticks with 15 per cent spinach were best accepted and nutrient analysis revealed that products were good source of energy, protein, fat, iron and fair source of ß-carotene, minerals like calcium, magnesium and zinc.
\end{abstract}

Keywords: pre-schoolers, food jags, nutri-dense, snacks, malnutrition

\section{Introduction}

Preschool children belong to the age group of 1-6 years. During this period, the growth is generally slower than first year of life but continues gradually. Because growth is slower, the appetite decreases, which often concerns the parents. Interest in food decreases and interest in world around them increases. They develop food jags during this time, refusing previously accepted food or asking for the same food each meal. Because of their smaller stomach capacity and variable appetites, the preschool children eat best with small servings of foods offered several times a day. Most of the children eat four to six times a day making snacks as important meals in contributing to the total daily nutrient intake (Krause's, 2000). Thus, snacks should be chosen wisely so that they are dense in nutrients. Preschool children constitute one of the most nutritionally vulnerable segments of the population. Nutrition during these years not only affects growth and morbidity in childhood but also has great impact on the nutritional status in adolescent and adult life.

National Family Health Survey- 4 (2015-16), India fact sheet for children under 5 years in urban area reported that 31 per cent were stunted, 20 per cent wasted, 7.5 per cent severely wasted and 29.1 per cent underweight and in rural area 41.2 per cent were stunted, 21.5 per cent wasted, 7.4 per cent severely wasted and 38.3 per cent underweight. The most common problems indicated are: protein energy malnutrition, vitamin A deficiency, anaemia, vitamin B complex deficiency and calcium deficiency.

Cereal grains are generally used as major raw materials for development of extruded snack foods due to their good expansion characteristics because of high starch content. (Shewry and Halford, 2001).Cereals contain about 6-15 per cent of protein (Goldberg, 2003).Protein content in wheat varies between 8 and 17 per cent. Gluten, comprises roughly 78 to 85 per cent of total wheat protein. Gluten is composed of glutenins and gliadins. Glutenins confer elasticity, while gliadins confer mainly viscous flow and extensibility to the gluten complex. Thus, gluten is responsible for most of the viscoelastic properties of wheat flour doughs and is the main factor dictating the use of a wheat variety in preparation of bakery items like bread, bread-sticks, cakes, cookies, pasta etc. (Mac Ritchie, 1994).

Pulses are important source of protein in vegetarian diet. It gives about $20-25$ per cent protein. Green gram is a widely consumed pulse and is an excellent source of protein (25 per cent), high in dietary fibre, rich source of vitamins and minerals. Combination of cereal and pulse provide protein at cheaper cost and suitable for highly populated country like India (Singh et al., 2014).Maize protein is deficient in lysine and tryptophan, soybean is limiting in sulphur amino acid, methionine but high in lysine. Therefore, soybean and maize blend would provide a nutritionally balanced food because of the improved protein. (Peter et al., 2012). Finger millet is exceptionally rich in calcium (344 mg) compared to all other cereals and millets (eightfold higher than pearl millet) and contains $283 \mathrm{mg}$ phosphorus, $3.9 \mathrm{mg}$ iron. Fruits and vegetables are protective foods and rich source of vitamins and minerals. Spinach and carrot are good source of $\beta$ carotene with 5580 and $1890 \mu \mathrm{g}$ respectively per $100 \mathrm{~g}$ (Gopalan et al., 2014).

Combination with food groups: cereals, millets, pulses, nuts and oilseeds, functional foods, vegetables and fruits can enhance the nutritive quality of food products thus, facilitates in developing various nutri-dense products for preschoolers.Hence with a view to reduce malnutrition in preschool children, nutrient dense products were formulated under present study.

\section{Literature Survey}

Mascola et al. (2010) conducted a study to examine the incidence, point prevalence, persistence and characteristics of picky eating during childhood. At any given age between 13 and 22 per cent of the children were reported to be picky eaters. Incidence declined over time whereas point prevalence increased indicating that picky eating is often a 


\section{International Journal of Science and Research (IJSR) \\ ISSN (Online): 2319-7064}

Index Copernicus Value (2015): 78.96 | Impact Factor (2015): 6.391

chronic problem with 40 per cent having a duration of more than 2-years. Those with longer duration differed from those with short duration having more strong likes and dislikes of food and not accepting new foods. Parents of picky eaters were more likely to report that their children consumed a limited variety of foods, required food prepared in specific ways, expressed stronger likes and dislikes for food, and threwtantrums when denied foods. They were also more likely to report struggles over feeding, preparing special meals, and commenting on their child's eating. Hence, it was concluded that picky eating is a prevalent concern of parents and may remain so through childhood.

Kostecka (2014) evaluated the eating habits and the diets of preschool children as risk factors for excessive weight, obesity, insulin resistance and the metabolic syndrome. The study was conducted on 350 randomly selected preschool children attending kindergartens. Three-day dietary recalls were processed and evaluated in the Dieta 5 application. Results showed that the analysed diets were characterized by low diversity and a high share of processed foods, such as pate, sausages, ketchup, mayonnaise, fried meat, French fries and fast-food. The dietary content of vegetables, raw fruit, dairy products and whole grain products was alarmingly low. It was concluded that, diets characterized by excessive energy value and nutritional deficiency can lead to health problems.

Bisla et al. (2012) conducted study to develop low cost nutrient dense supplementary products for children by using locally available cereals, soy flour, Bengal gram leaves and cow pea leaves. Malnourished children are often victim of various infections like weight loss, iron deficiency, iodine deficiency, vitamin A deficiency etc. As with underweight, the prevalence of different micronutrient deficiencies varies widely across states. Prevention of malnutrition can be started by providing nutrient dense supplementary foods to the children.

\section{Methodology}

Formulation of product: The materials required for the present study were procured from local market. Multi-nutri chips were formulated by adding cereals, millet, pulses, oilseed, vegetable and fruit. Two variations were prepared viz., Fried (FNC), baked (BNC). A mix of banana, potato and corn chips was considered as control. Veggi sticks were developed by replacing refined wheat flour with wheat: soy flour $(9: 1)$. Three variations with value addition by spinach leaves at 5, 10 and 15 per cent incorporation level viz., VS1, VS2, and VS3 respectively were prepared. Sticks prepared from refined wheat flour without addition of spinach were treated as control.

Sensory evaluation: A 9-point hedonic scale (Peryam \& Pilgrim, 1957) was used for organoleptic evaluation. The products were evaluated for their appearance, texture, colour, aroma/flavour, taste and overall acceptability by 21 semi trained panel members.

Nutrient analysis: The developed products were analysed for moisture, ash, protein, fat, crude fibre calcium using AOAC (1980) methods. Minerals like iron, copper, zinc, magnesium and manganese were estimated using AAS (Atomic Absorption Spectrophotometer) method. Estimation of $\beta$-carotene and vitamin $\mathrm{C}$ was done as per method quoted by Ranganna, 1996.

Statistical analysis: Data was analysed using one-way analysis of variance (ANOVA) and in randomized complete block design to determine the level of significance.

\section{Results and Discussion}

\section{Sensory evaluation}

Snacks food items are preferred by children over complete meals, thus improving the nutrient density of snacks is important to meet their nutritional requirements. The designed products viz., nutri chips and veggi sticks along with control samples were subjected to sensory evaluation.

Results of sensory evaluation are presented in Fig. 1 and 2.It is evident from the results thatVS3 with 15 per cent of the spinach leaves was best accepted in all the sensory attributes, this could be possibly due to green colour imparted by spinach leaves making it more appealing (Fig. 1). Value addition with spinach leaves, replacing refined wheat flour with combination of wheat and soya flour (9:1) enhanced the sensory scores for all the attributes as compared to control sticks. Similar study was conducted by Ndife et al. (2011) who developed functional bread by substituting soybean flour in wheat flour and it was observed that substitution of 10 per cent soy flour into wheat flour gave best overall quality and acceptability to the bread. Reddy et al.(2005) developed biscuits treated with amla (Emblica officianalis), drumstick leaves (Moringa oleifera) and raisins (Vitis vinifera) as sources of natural antioxidants and it was observed that biscuits treated with raisins and drumstick leaves received higher panel scores, than control.

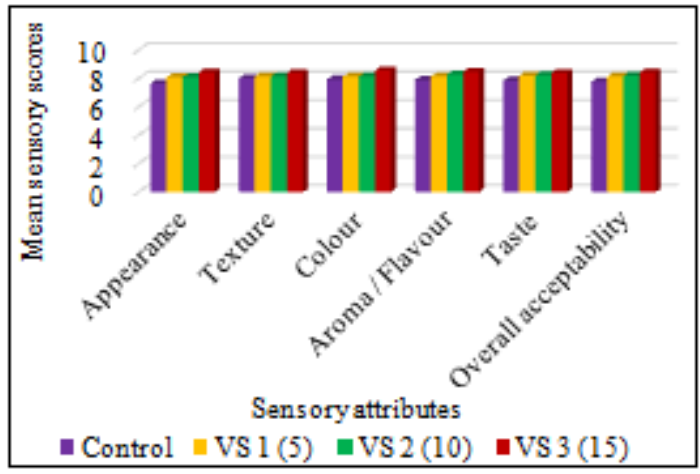

Figure 1: Mean sensory scores of veggi sticks

Sensory analysis for nutri chips revealed that Fried chips were most acceptable followed by control and baked chips (FNC >control> BNC). The sensory scores are represented in Fig. 2. Deep fried chips (FNC) was best accepted as deep frying resulted in development of desirable sensory properties due to high heat transfer rates. Use of sunflower oil during frying might have enhanced taste, aroma and flavour of the fried product as sunflower oil is reported to have high linoleic acid and linolenic acid contents (Fuller et al., 1967).The scores for colour was high in fried nutri chips because different ingredients like maize, ragi, soybean, green gram, potato, banana, carrot and garden cress seeds made the chips more appealing and colourful. Ghag and 


\section{International Journal of Science and Research (IJSR) \\ ISSN (Online): 2319-7064}

Index Copernicus Value (2015): 78.96 | Impact Factor (2015): 6.391

Sengupta (2014) reported similar results for multigrain crispy chips prepared by adding bajra, jowar, soyabean, rice flakes, flaxseeds and dried fenugreek.

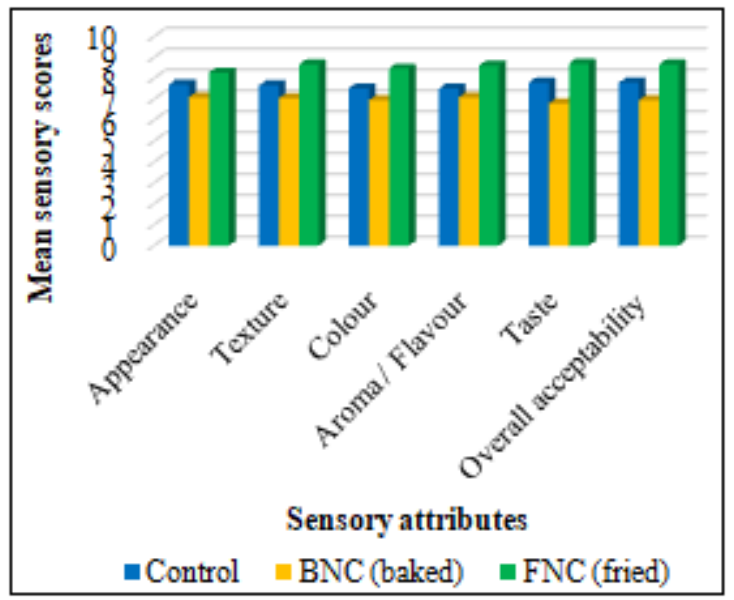

Figure 2: Mean sensory scores of nutri chips

\section{Nutrient analysis}

The nutrient content of VS3 for protein, fat, carbohydrates, energy and crude fibre was $15.18 \mathrm{~g}, 14.60 \mathrm{~g}, 54.70 \mathrm{~g}, 409$ Kcal and $1.55 \mathrm{~g}$ respectively. Moisture (7.60) and ash (6.90) content of VS 3 was recorded higher than control. Control sample was more energy dense $(425 \mathrm{Kcal})$ as compared to the VS3 variation with $409 \mathrm{Kcal}, \beta$-carotene content was high in VS3 $(1306.20 \mu \mathrm{g})$ than control $(40 \mu \mathrm{g})$ due to addition of spinach leaves. Nutrient content of veggi sticks increased in the VS3 variation than the control due to value addition of spinach leaves and replacement of refined wheat flour by whole wheat and soy flour at 9:1 ratio. Statistically all the nutrients showed significant difference, except for fat as compared to control.100 g of veggi sticks (VS3) are able to provide more amount of protein, fat, iron and zinc than one third amount of nutrient required by preschool children of 4-6 years (RDA, 2010). Per serving the child can consume $50 \mathrm{~g}$ of sticks. The study conducted by Ndife $e t$ al. (2011) supported the results obtained in this study for functional breads prepared with addition of 10 per cent soya flour.

Table 1: Nutrient composition of veggi sticks (100 g)

\begin{tabular}{|c|c|c|c|c|c|}
\hline Nutrients & Control & $\begin{array}{c}\text { VS3 } \\
(15 \%)\end{array}$ & $\begin{array}{c}\text { F- } \\
\text { value }\end{array}$ & SEm \pm & $\begin{array}{c}\text { CD at } 5 \\
\%\end{array}$ \\
\hline Moisture (\%) & 7.00 & & $*$ & 0.058 & 0.227 \\
\hline Protein $(\mathrm{g})$ & & 15.18 & $*$ & 0.119 & 0.469 \\
\hline Fat $(\mathrm{g})$ & 15.00 & 14.60 & $\mathrm{NS}$ & 0.422 & 1.658 \\
\hline Crude Fibre (g) & 0.53 & 1.55 & $*$ & 0.015 & 0.061 \\
\hline Carbohydrate (g) & 64.80 & 54.70 & $*$ & 0.964 & 3.783 \\
\hline Energy (Kcal) & 425 & 409 & $*$ & 1.716 & 6.738 \\
\hline Ash (g) & 4.80 & 6.90 & $*$ & 0.044 & 0.174 \\
\hline Calcium $(\mathrm{mg})$ & 27.00 & 95.10 & $*$ & 0.923 & 3.624 \\
\hline Iron $(\mathrm{mg})$ & 2.80 & 7.00 & $*$ & 0.157 & 0.616 \\
\hline Magnesium $(\mathrm{mg})$ & 7.00 & 13.00 & $*$ & 0.422 & 1.658 \\
\hline Copper $(\mathrm{mg})$ & 0.12 & 0.76 & $*$ & 0.014 & 0.055 \\
\hline Manganese (mg) & 0.50 & 1.59 & $*$ & 0.041 & 0.161 \\
\hline Zinc $(\mathrm{mg})$ & 1.10 & 2.39 & $*$ & 0.055 & 0.216 \\
\hline $\begin{array}{c}\beta-C a r o t e n e \\
(\mu \mathrm{g})\end{array}$ & 40.00 & 1306.20 & $*$ & 0.476 & 1.869 \\
\hline
\end{tabular}

*Significant at $5 \%$ level; NS- Non-significant

Control: refined wheat flour

VS $3(15 \%)$ : wheat + soy flour (90:10), 15 per cent spinach
Nutrient content of nutri chips are given in Table 2. The nutrient content of FNC for protein, fat, carbohydrates energy and crude fibre was $10.10 \mathrm{~g}, 20.5 \mathrm{~g}, 58.88 \mathrm{~g}, 460$ Kcal and $2.32 \mathrm{~g}$ respectively. Moisture and ash content was higher in FNC sample (5.27 per cent and $2.93 \mathrm{~g}$ ) than control sample (4.68 per cent and $1.96 \mathrm{~g}$ ). $\beta$-carotene content was $148.7 \mu \mathrm{g}$ in FNC no carotene content was detected in control. Calcium and iron in FNC was reported as $80.30 \mathrm{mg}$ and $5.73 \mathrm{mg}$ respectively. Other mineral content of magnesium, copper, manganese and zinc was $2.15 \mathrm{mg}, 0.60$ $\mathrm{mg}, 0.82$ and $1.92 \mathrm{mg}$ respectively fried nutri chips. Statistical analysis showed significant difference between nutrients, only carbohydrate remained statistically nonsignificant.

Nutri chips have better nutrient profile than control products due to presence of wheat, maize, ragi, soybean, green gram, potato, banana, carrot and garden cress seeds. Garden cress seeds contribute to the iron content, carrots provided carotene, pulses like green gram and soybean provided protein, ragi improved the calcium content of chips. Ghag and Sengupta (2014) reported concurrent results with higher nutritive value for energy (584 Kcal), protein $(23.68 \mathrm{~g})$, fat (21.97), carbohydrate (69.18 g) and fibre (17 g) for multigrain crispy chips.

Table 2: Nutrient composition of nutri chips (100 g)

\begin{tabular}{|c|c|c|c|c|c|}
\hline Nutrients & Control & $\begin{array}{c}\text { FNC } \\
\text { (fried) }\end{array}$ & F-value & SEm \pm & $\begin{array}{c}\text { CD at } \\
5 \%\end{array}$ \\
\hline Moisture $(\%)$ & 4.68 & 5.27 & $*$ & 0.069 & 0.273 \\
\hline Protein $(\mathrm{g})$ & 3.00 & 10.10 & $*$ & 0.046 & 0.179 \\
\hline Fat $(\mathrm{g})$ & 30.00 & 20.50 & $*$ & 0.204 & 0.801 \\
\hline Crude Fibre $(\mathrm{g})$ & 2.10 & 2.32 & $*$ & 0.087 & 0.343 \\
\hline Carbohydrate $(\mathrm{g})$ & 58.26 & 58.88 & $\mathrm{NS}$ & 0.191 & 0.748 \\
\hline Energy $(\mathrm{Kcal})$ & 425 & 460 & $*$ & 1.700 & 6.674 \\
\hline Ash $(\mathrm{g})$ & 1.96 & 2.93 & $*$ & 0.049 & 0.193 \\
\hline Calcium $(\mathrm{mg})$ & 0.00 & 80.30 & $*$ & 0.055 & 0.215 \\
\hline Iron $(\mathrm{mg})$ & 0.36 & 5.73 & $*$ & 0.072 & 0.283 \\
\hline Magnesium $(\mathrm{mg})$ & 0.98 & 2.15 & $*$ & 0.062 & 0.244 \\
\hline Copper $(\mathrm{mg})$ & 0.00 & 0.60 & $*$ & 0.020 & 0.080 \\
\hline Manganese $(\mathrm{mg})$ & 0.00 & 0.82 & $*$ & 0.012 & 0.048 \\
\hline Zinc $(\mathrm{mg})$ & 0.50 & 1.92 & $*$ & 0.078 & 0.308 \\
\hline$\beta$-Carotene $(\mu \mathrm{g})$ & 0.00 & 148.70 & $*$ & 0.187 & 0.735 \\
\hline Vit C $(\mathrm{mg})$ & 0.00 & 3.25 & $*$ & 0.061 & 0.240 \\
\hline
\end{tabular}

*Significant at $5 \%$ level; NS- Non-significant

Control: banana, potato and corn chips

Fried nutri chips (FNC)

\section{Conclusion}

Pre-schoolers are fond of nibbling in between meals instead of having complete meals. The present study carried out on development of nutrient dense foods for preschool children revealed that combination of different food groups (cereals/millets, pulses, nuts and oilseeds, roots and tubers, green leafy vegetable, fruits, fats and oils) can improve the nutrient content of foods products which pre-schoolers are fond of munching and snacking. Enhancement in the sensory attributes was observed in the prepared products than control samples.

\section{Volume 6 Issue 7, July 2017 www.ijsr.net}




\section{International Journal of Science and Research (IJSR)}

ISSN (Online): 2319-7064

Index Copernicus Value (2015): 78.96 | Impact Factor (2015): 6.391

\section{Future Scope}

Further investigation can be conducted to develop more such nutrient dense products and commercialize them.

\section{References}

[1] A. O. A. C., 1980, Official methods of analysis 13th Edn. Association of Official Analytical chemists, Washington, D.C.

[2] ANONYMOUS, 2015-16, NFHS-4: National Family Health Surveys, National fact sheet - India. www.nfhsindia.org.

[3] BISLA, G., ARCHANA, AND PAREEK, S., 2012, Development of nutrient dense supplementary products for children by using locally available cereals, soy flour, bengal gram leaves and cow pea leaves. Asian J. Plant Sci. Res., 2 (4): 396-402.

[4] GHAG, A. AND SENGUPTA, R., 2014, Effects of multigrain chips on cardio vascular disease (CVD). Int. J. Food Nutritional Sci., 3(3): 189-192.

[5] GOLDBERG G., 2003, Plants: Diet and Health. The Report of the British Nutrition Foundation Task Force. Blackwell, Oxford.

[6] GOPALAN, C., RAMA SASTRI, B. V. AND BALASUBRAMANIAN, S. C., 2014, Nutritive value of Indian foods. National Institute of Nutrition, Indian Council of Medical Research. Hyderabad, India. 40-95.

[7] KOSTECKA, M., 2014, Eating habits of preschool children and the risk of obesity, insulin resistance and metabolic syndrome in adults. Pak. J. Med. Sci., 30(6):1299-1303.

[8] KRAUSE'S, 2000, Nutrition in Childhood. In: Food, Nutrition and Diet Therapy, pp: 271-272.

[9] MACRITCHIE, F., 1994, Role of polymeric proteins in flour functionality. In Wheat kernel proteins: molecular and functional aspects, Bitervo, Italy, Universita degli studi della Tuscia. 145-150.

[10] MASCOLA, A. J., BRYSON, S. W. AND AGRAS, W. S., 2010, Picky eating during childhood: A longitudinal study to age 11-years. Eat Behav., 11(4): 253-257.

[11] NDIFE, J., ABDULRAHEEM, L. O. AND ZAKARI, U. M., 2011, Evaluation of the nutritional and sensory quality of functional breads produced from whole wheat and soya bean flour blends. Afr. J. Food Sci., 5(8): 466 -472 .

[12] PETER, R., SHEWRY, NIGEL, G. AND HALFORD, 2012, Cereal seed storage proteins: structures, properties and role in grain utilization. J. Exp. Bot., 53: 947-958.

[13] PREYAM, D. R. AND PILGRIM, F. J., 1957, Hedonic scale Method of Measuring Food Preferences. Food Technol., 11(9): 1-13.

[14]RANGANNA, S., 1996, Handbook of analysis and quality control for fruits and vegetable products. $2^{\text {nd }}$ Edn. Tata McGraw-Hill, Pub. Co. Ltd., New Delhi,pp.84-86.

[15] REDDY, V., UROOJ, A, AND KUMAR, A., 2005, Evaluation of antioxidant activity of some plant extracts and their application in biscuits. Food Chem., 90: 317321.
[16] SHEWRY, P. R. AND HALFORD, F.,2001, Cereal seed storage proteins:structures, properties and role in grain utilization. J.Exp. Bot., 53(370): 947-958.

[17] SINGH, D. S., AMOL, PARE, A., SINGH, M. AND SETH, N., 2014, Extrusion Characteristic of Bengal Gram Brokens and Maize Flour Blends for Preparation of Extruded Snack Food. J. Agril. Search, 1 (1):13-18.

\section{Authors Profile}

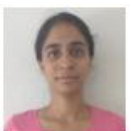

Barbhai Mrunal D., MSc Student, Department of Food Science and Nutrition, University of Agricultural Sciences, GKVK, Bengaluru -65

Dr. Vijayalakshmi D., Professor and Head, Dept. Food Science and Nutrition, University of Agricultural Sciences, GKVK, Bengaluru -65

Dr. Subbarayappa C. T., Professor, Dept. of Soil Science and Agricultural Chemistry, University of Agricultural Sciences, GKVK, Bengaluru -65 